\title{
Adult Neurogenesis in the Female Mouse Hypothalamus: Estradiol and High-Fat Diet Alter the Generation of Newborn Neurons Expressing Estrogen Receptor $\alpha$
}

\author{
(1)Elizabeth P. Bless, ${ }^{1}$ Jane Yang, ${ }^{1}$ (1) Kalpana D. Acharya, ${ }^{1}$ Sabin A. Nettles, ${ }^{1}$ (D)Fair M. Vassoler, ${ }^{2}$ \\ Elizabeth M. Byrnes, ${ }^{2}$ and ${ }^{1}$ Marc J. Tetel ${ }^{1}$
}

DOI:http://dx.doi.org/10.1523/ENEURO.0027-16.2016

${ }^{1}$ Neuroscience Program, Wellesley College, Wellesley, Massachusetts 02481, and ${ }^{2}$ Department of Biomedical Sciences, Cummings School of Veterinary Medicine, Tufts University, Grafton, Massachusetts 01536

\section{Visual Abstract}

\section{BrdU}

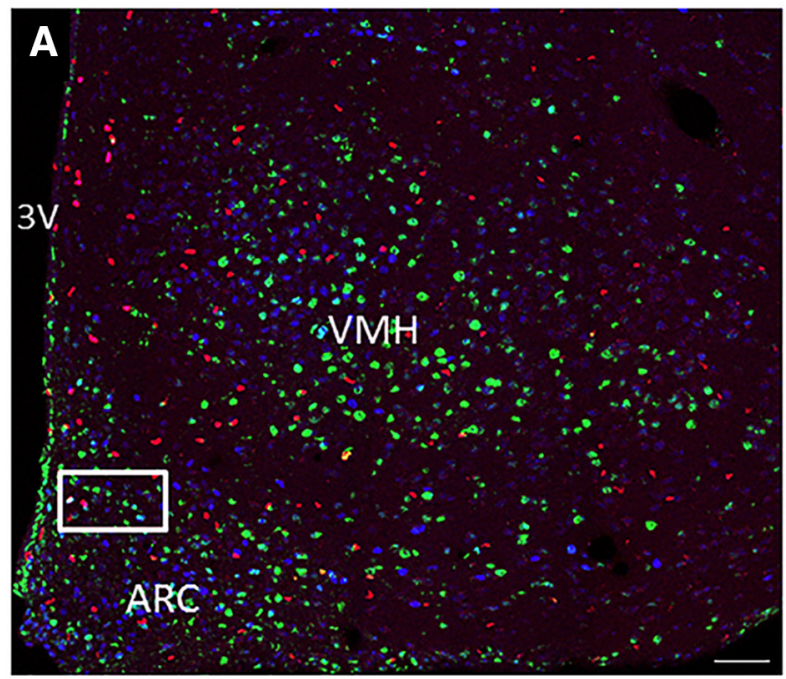

(new cells)
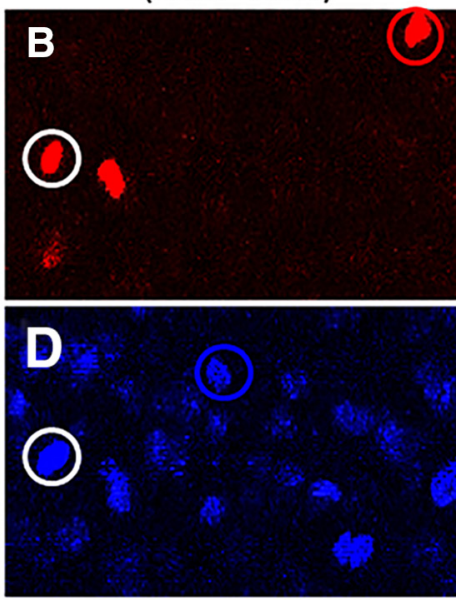

pSTAT3

(leptin-sensitive)
$E R \alpha$

(estrogen-sensitive)

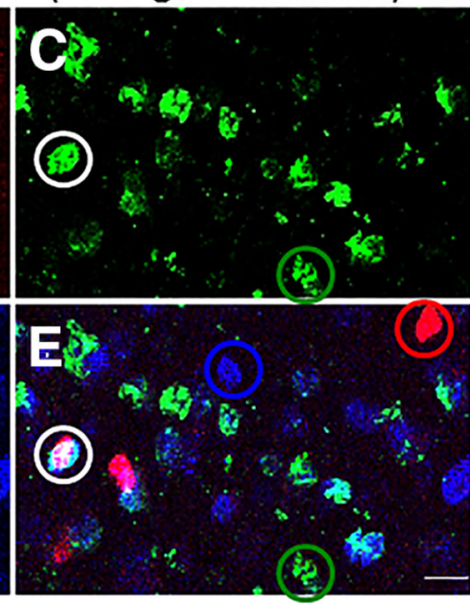

Merged

\section{Significance Statement}

Estrogens and leptin act in the hypothalamus to profoundly impact energy homeostasis in humans and rodents. For example, postmenopausal women gain weight, increasing their risk for heart disease and diabetes. Hypothalamic neurogenesis has been implicated in energy homeostasis in adult male and female rodents. In the present study, newborn neurons that respond to estrogens and leptins were identified in the adult female mouse hypothalamus. Moreover, the generation of these newborn hypothalamic neurons was regulated by estradiol and a high-fat diet (HFD). Estradiol decreased hypothalamic Fgf10 gene expression in mice consuming an HFD, suggesting a role for Fgf10 in estradiol effects on neurogenesis. These findings provide a novel mechanism by which estrogens can act in the female hypothalamus to regulate energy homeostasis. 
Estrogens and leptins act in the hypothalamus to maintain reproduction and energy homeostasis. Neurogenesis in the adult mammalian hypothalamus has been implicated in the regulation of energy homeostasis. Recently, high-fat diet (HFD) and estradiol (E2) have been shown to alter cell proliferation and the number of newborn leptin-responsive neurons in the hypothalamus of adult female mice. The current study tested the hypothesis that new cells expressing estrogen receptor $\alpha(\mathrm{ER} \alpha)$ are generated in the arcuate nucleus (ARC) and the ventromedial nucleus of the hypothalamus $(\mathrm{VMH})$ of the adult female mouse, hypothalamic regions that are critical in energy homeostasis. Adult mice were ovariectomized and implanted with capsules containing E2 or oil. Within each hormone group, mice were fed an HFD or standard chow for 6 weeks and treated with BrdU to label new cells. Newborn cells that respond to estrogens were identified in the ARC and $\mathrm{VMH}$, of which a subpopulation was leptin sensitive, indicating that the subpopulation consists of neurons. Moreover, there was an interaction between diet and hormone with an effect on the number of these newborn ER $\alpha$-expressing neurons that respond to leptin. Regardless of hormone treatment, HFD increased the number of ER $\alpha$-expressing cells in the ARC and VMH. E2 decreased hypothalamic fibroblast growth factor 10 (Fgf10) gene expression in HFD mice, suggesting a role for Fgf10 in E2 effects on neurogenesis. These findings of newly created estrogen-responsive neurons in the adult brain provide a novel mechanism by which estrogens can act in the hypothalamus to regulate energy homeostasis in females.

Key words: estrogens; leptin; obesity; pSTAT3

\section{Introduction}

The peripheral maintenance of energy homeostasis in mammals is profoundly influenced by hormone signaling. In particular, estrogens affect energy homeostasis through the regulation of adiposity (Heine et al., 2000; Naaz et al., 2002), activity (Wade, 1972; Blaustein and Wade, 1976), and thermogenesis (Hosono et al., 1997; Opas et al., 2006). For example, postmenopausal women gain fat weight, which increases their risk for heart disease and type 2 diabetes (Guo et al., 1999; Carr, 2003). In support of these anorectic effects of estrogens, ovariectomized rodents demonstrate a decrease in activity, and an increase in feeding and weight gain (Wade, 1972; Xu et al., 2011). Investigations of the central effects of estrogens on energy homeostasis have focused on neuropeptide expression in hypothalamic areas (Frank et al., 2014). For example, estradiol (E2) decreases mRNA expression of orexigenic factors [e.g., neuropeptide Y (NPY) and Agouti-related protein; Pelletier et al., 2007; Silva et al., 2010] and increases mRNA expression of anorexigenic factors [e.g., pro-opiomelanocortin (POMC) in the arcuate nucleus (ARC) of ovariectomized mice and rats; Pelletier

Received February 11, 2016; accepted August 23, 2016; First published August 29, 2016

The authors declare no competing financial interests.

Author contributions: E.P.B., E.M.B., and M.J.T. designed research; E.P.B., J.Y., K.D.A., S.A.N., and F.M.V. performed research; E.P.B., K.D.A., S.A.N., F.M.V., E.M.B., and M.J.T. analyzed data; E.P.B., E.M.B., and M.J.T. wrote the paper

This work was funded by National Institutes of Health Grant R01-DK-61935 (to M.J.T.) and a Re-entry Award (to E.P.B.) from the National Institute of Diabetes and Digestive and Kidney Diseases.

Acknowledgments: We thank Barbara Beltz for helpful comments on the manuscript.

Correspondence should be addressed to Marc J. Tetel, Neuroscience Program, Wellesley College, 106 Central Street, Wellesley, MA 02481. E-mail: mtetel@wellesley.edu.

DOI:http://dx.doi.org/10.1523/ENEURO.0027-16.2016

Copyright @ 2016 Bless et al.

This is an open-access article distributed under the terms of the Creative Commons Attribution 4.0 International, which permits unrestricted use, distribution and reproduction in any medium provided that the original work is properly attributed. et al., 2007]. While estrogen receptor (ER) $\alpha, \mathrm{ER} \beta$, and membrane-associated ER have been implicated in estrogen effects on energy homeostasis (Qiu et al., 2006; Frank et al., 2014), ER $\alpha$ appears to contribute more to energy homeostasis (Heine et al., 2000; Santollo et al., 2007, 2010; Frank et al., 2014). Importantly, $\mathrm{ER} \alpha$ function in the hypothalamus is critical in weight maintenance (Musatov et al., 2007; Xu et al., 2011).

Leptin, secreted by adipose tissue, acts in the hypothalamus to play a critical role in energy homeostasis (Sahu, 2003; Varela and Horvath, 2012; Rosenbaum and Leibel, 2014; Park and Ahima, 2015). There is cross talk between the estrogen and leptin signaling pathways in the regulation of weight, adiposity, and energy intake and expenditure (Gao and Horvath, 2008; Clegg, 2012; Nestor et al., 2014). Leptin effects on energy homeostasis are enhanced by estrogens (Ainslie et al., 2001; Clegg et al., 2006). In support, leptin receptors are colocalized with ERs in the ARC of the rat (Diano et al., 1998). It has been suggested that the signaling of these two hormones overlap via phosphorylation of the downstream signaling molecule, signal transducer and activator of transcription-3 (STAT3; Gao and Horvath, 2008).

Much is known about the generation of new neurons in the olfactory bulb and the dentate gyrus of the adult hippocampus (Zhao et al., 2008). A variety of factors influences cell proliferation and neurogenesis in the hippocampus, including estrogens (Galea et al., 2006; Pawluski et al., 2009; Duarte-Guterman et al., 2015). In addition, neurogenesis has also been observed in the adult mammalian hypothalamus, and recent work has focused on the origin and function of these new cells (Lee et al., 2012; Haan et al., 2013; Rojczyk-Gołębiewska et al., 2014). New cells in the hypothalamus are affected by diet (Lee et al., 2012; Li et al., 2012; McNay et al., 2012; Gouaze et al., 2013; Bless et al., 2014), and help to regulate energy homeostasis in male mice (Kokoeva et al., 2005; Pierce and Xu, 2010; Lee et al., 2012; Gouaze et al., 2013; Li et al., 2014) and female mice (Lee et al., 2014). In addition, high-fat diet (HFD) and E2 alter cell proliferation 
and neurogenesis in the ARC and ventromedial nucleus of the hypothalamus $(\mathrm{VMH})$ of adult female mice (Bless et al., 2014). Furthermore, HFD and E2 affect the number of newborn leptin-responsive [phosphorylated STAT3 (pSTAT3)-expressing] neurons in the female hypothalamus (Bless et al., 2014).

The current study tested the hypothesis that the adult female mouse brain is capable of generating new ER $\alpha$ expressing cells in the ARC and $\mathrm{VMH}$. In addition, we asked whether newly generated $\mathrm{ER} \alpha$ cells were also leptin sensitive. Last, a variety of growth factors, cytokines, and apoptotic factors influence adult neurogenesis in the mammalian hippocampus, olfactory bulb, and hypothalamus (Endres et al., 1998; Fink et al., 1998; Pencea et al., 2001; Kokoeva et al., 2005; Sasaki et al., 2006; Zhang et al., 2006; Yuan, 2008; Zhao et al., 2008; Choi et al., 2009; Li et al., 2012). The expression of some of these factors was examined in the hypothalamus for their potential role in increasing cell proliferation in obese female mice consuming an HFD.

\section{Materials and Methods}

\section{Animals}

For the immunohistochemistry experiments, a set of brain sections from a previously published study (Bless et al., 2014) was used. Briefly, C57BL/6 female mice (10-12 weeks of age) from the breeding colony were housed two per cage and maintained on a $12 \mathrm{~h}$ light/dark cycle. Mice were bilaterally ovariectomized and implanted subcutaneously with a silastic capsule (Ingberg et al., 2012) containing either $50 \mu \mathrm{g}$ of $17 \beta$-E2 dissolved in $25 \mu \mathrm{l}$ of $5 \% \mathrm{ETOH} /$ sesame oil (Rissman et al., 2002; Kudwa et al., 2009) or vehicle (Veh; 5\% ETOH/sesame oil). Three days after surgery, mice were either started on an HFD containing $58 \% \mathrm{kcal}$ from fat in the form of lard $(35.2 \%$ fat, $36.1 \%$ carbohydrate, and $20.4 \%$ protein by weight; catalog \#03584, Harlan Teklad) or maintained on standard rodent chow (STND) containing $13.5 \%$ kcal from fat (catalog \#5001, Purina).

Mice were randomly assigned to one of the following four treatment groups: STND-Veh $(n=5)$; STND-E2 $(n=$ $6) ;$ HFD-Veh $(n=9)$; and HFD-E2 $(n=8)$. Six animals that did not receive the complete BrdU infusion due to the loss of the cannula during the experiment $(n=4)$ or the cannula missing the lateral ventricle $(n=2)$ were excluded from the analysis. Mice were weighed every $5 \mathrm{~d}$, and the amount of food eaten was recorded every other day (1-2 $\mathrm{h}$ before lights off) throughout the study. Seven days after ovariectomy/silastic capsule implantation, mice were implanted with a cannula aimed at the right lateral ventricle [anteroposterior (AP), $0.3 \mathrm{~mm}$; ML, $1.0 \mathrm{~mm}$ from bregma; DV, $2.5 \mathrm{~mm}$; Paxinos and Franklin, 2004]. The cannula was attached to an Alzet osmotic pump (0.5 $\mu \mathrm{l} / \mathrm{h}, 7 \mathrm{~d}$; catalog \#1007D, Durect) filled with $100 \mu$ of home-made artificial CSF containing $1 \mu \mathrm{g} / \mu \mathrm{l}$ BrdU (Sigma-Aldrich) and $1 \mu \mathrm{g} / \mu \mathrm{l}$ mouse serum albumin (Sigma-Aldrich) via a catheter. Mice were maintained on their respective diets for 34 $\mathrm{d}$ after the start of BrdU infusion to allow newborn cells to become functionally mature (van Praag et al., 2002; Kim et al., 2014b). Thirty-four days after the start of BrdU infusion, mice were deprived of food overnight. On the next day, cardiac perfusion with $4 \%$ paraformaldehyde was performed 45 min after an injection of leptin $(5 \mathrm{mg} / \mathrm{kg}$, i.p.; Peprotech). Leptin was administered in order to induce phosphorylation of STAT3 in the hypothalamus (Frontini et al., 2008). Following perfusion, brains were dissected out, postfixed in 4\% paraformaldehyde for $2 \mathrm{~h}$ and then transferred to $20 \%$ sucrose/0.1 M phosphate buffer for $2 \mathrm{~d}$ until sectioning. Thirty-five-micrometer-thick brain sections were cut on a freezing microtome and stored in cryoprotectant at $-20^{\circ} \mathrm{C}$ until processing.

\section{Gene expression analysis by reverse transcription- quantitative PCR}

For the reverse transcription-quantitative PCR (RTqPCR) studies, C57BL/6 female mice (8-10 weeks) from Wellesley College Animal Facility were housed on a $12 \mathrm{~h}$ light/dark cycle. The mice were bilaterally ovariectomized and implanted with a silastic capsule containing either 50 $\mu \mathrm{g}$ of E2 dissolved in $25 \mu \mathrm{l}$ of $5 \% \mathrm{ETOH} /$ sesame oil $(n=$ $7)$ or Veh (5\% ETOH/sesame oil; $n=7)$. On day 11 after ovariectomy and capsule implantation, mice were started on an HFD, as described above. All animal procedures were approved by the Institutional Animal Care and Use Committee and were conducted in accordance with the National Institutes of Health Guide for the Care and Use of Laboratory Animals.

\section{Triple-label immunohistochemistry}

Sections from the anterior, medial, and posterior ARC (based on mouse brain atlas of Paxinos and Franklin, 2004; AP: $-1.46,-2.06$, and -2.54 , respectively) and VMH (AP: $-1.22,-1.7$, and -2.06 , respectively) were selected for analysis. Brain sections were rinsed in $0.05 \mathrm{M}$ Tris-buffered saline (TBS), incubated in TBS containing $0.01 \mathrm{M}$ glycine for $30 \mathrm{~min}$, rinsed, and then incubated in TBS containing $0.05 \%$ sodium borohydride for 20 min to reduce autofluorescence as a result of aldehyde fixation. DNA was denatured for BrdU detection by incubating tissue in $2 \mathrm{~N} \mathrm{HCl}$ at $40^{\circ} \mathrm{C}$ for 40 min followed by rinses in borate buffer, $\mathrm{pH} 8.5$, and TBS. Nonspecific antigenbinding sites were blocked with TBS containing $0.4 \%$ Triton X, 10\% normal serum (donkey and goat; Lampire Biological), and $1 \%$ hydrogen peroxide for $30 \mathrm{~min}$. Sections were incubated overnight at $4^{\circ} \mathrm{C}$ in a primary antibody cocktail containing rat anti-BrdU [dilution, 1:400; OBT0030G (RRID:AB_609567), Accurate] and rabbit anti$\mathrm{ER} \alpha$ directed against the $\mathrm{N}$-terminal amino acids 21-32 of human ER $\alpha$ [dilution, 1:100; AB3575 (RRID:AB_303921), Abcam]. Tissue was washed in TBS followed by incubation with goat anti-rabbit Fab fragment $(30 \mu \mathrm{g} / \mathrm{ml}$; 111006-003 (RRID:AB_2337920), Jackson ImmunoResearch Laboratories) for $2 \mathrm{~h}$ at room temperature. This step was necessary because two antibodies raised in the same host species (rabbit) were used. The goat anti-rabbit Fab fragment was used to block the rabbit antigen sites so that another antibody produced in rabbit (anti-pSTAT3) could be used without cross signaling (https://www.jacksonimmuno. com/technical/products/protocols/double-labeling-samespecies-primary). Sections were rinsed with TBS and incubated in a cocktail of fluorescently labeled secondary 
antibodies including donkey anti-rat (dilution, 1:200; Cy3, Jackson ImmunoResearch Laboratories), and donkey anti-goat (dilution, 1:200; Alexa Fluor 488, Life Technologies) for $2 \mathrm{~h}$ at room temperature followed by rinses in TBS. Tissue was then incubated in rabbit anti-pSTAT3 [dilution 1:50; catalog \#9145 (RRID:AB_2491009), Cell Signaling Technology] overnight at $4^{\circ} \mathrm{C}$. The pSTAT3 antibody recognizes STAT3 only when it is phosphorylated at tyrosine 705. As shown on Western blot, this antibody binds to a specific band at $\sim 79 \mathrm{kDa}$ in hypothalamic tissue from mice injected with leptin (Bless et al., 2014). Tissue was then rinsed in TBS and incubated in donkey anti-rabbit (dilution, 1:200; Alexa Fluor 647, Life Technologies), followed by washes in TBS. Sections were mounted on SuperFrost Plus slides (Fisher), coverslips were applied with Fluorogel (Electron Microscopy Sciences), and slides were stored at $4^{\circ} \mathrm{C}$ until confocal analysis.

A variety of controls were performed to confirm the specificity of this triple-label technique. To ensure that there was no cross-labeling between the two rabbit antibodies (ER $\alpha$ and pSTAT3), the same protocol described above was conducted with the omission of the primary antibody for either ER $\alpha$ or pSTAT3. There was no cellular labeling detected with the donkey anti-rabbit Alexa Fluor 647 or donkey anti-goat Alexa Fluor 488, respectively, indicating that there was no cross-labeling by either of these secondary antibodies for the inappropriate primary antibody, thus resulting in no false labeling of $\mathrm{ER} \alpha$ - or pSTAT3-containing cells.

\section{Confocal microscopy}

Images of the left hemisphere (contralateral to BrdU administration) of each brain region were taken at $400 \times$ with a TCS SP5 II Confocal Microscope (Leica Microsystems) equipped with an argon laser 488, a helium-neon laser 543, a helium-neon laser 633, and a motorized stage. In total, the following six regions of interest (ROIs) were imaged according to Paxinos and Franklin (2004): three ROls representing the anterior, medial, and posterior levels of the ARC; and three ROIs representing the anterior, medial, and posterior levels of the VMH. Gain and offset settings were optimized for each fluorescent label separately for each ROI, and these settings were kept constant for all images within an ROI. A stack of 10 sections (1 $\mu \mathrm{m}$ each) was taken through the $z$-plane of each ROI.

\section{Image analysis}

Images were analyzed using the Nikon NIS Elements Advanced Research software (version 3.22; RRID:SCR 002776). The size and position of each ROI was kept constant across images. One section per ROI was examined, and the total area analyzed for each ROI was as follows: ARC: 83,362, 57,170, and 128,323 $\mu \mathrm{m}^{2}$, respectively, for anterior, medial, and posterior; and $\mathrm{VMH}$ : $90,071,156,401$, and $122,316 \mu \mathrm{m}^{2}$, respectively, for anterior, medial, and posterior.

Images resulting from the excitation of each of the three laser channels were merged to create a single RGB image. Each image was calibrated using a scale bar of 100 $\mu \mathrm{m}$. A threshold intensity to optimize the signal-to-noise ratio for each RGB channel was set and kept constant across all images of an ROI. Size (minimum-maximum, $5-70)$ and circularity $(0.35-1)$ restrictions were applied to distinguish cells from background. In each ROI, the number of immunoreactive cells (clustered pixels above threshold) and the average pixel intensity of each cell were collected for $\operatorname{BrdU}$, ER $\alpha$, and pSTAT3.

Brain sections from the same animals used in a previous study (Bless et al., 2014) that had been immunolabeled for the neuronal marker Hu, pSTAT3, and BrdU were analyzed to determine the percentage of pSTAT3labeled cells that also expressed $\mathrm{Hu}$, and thus were neurons. Three mice from each experimental group were randomly selected for the analysis. Thirty PSTAT3-labeled cells of varying intensities were randomly chosen from the medial ARC and VMH to examine the coexpression of $\mathrm{Hu}$ in these cells.

\section{TaqMan RT-qPCR}

Brain dissection

Thirty-five days after the start of the HFD, mice were killed via $\mathrm{CO}_{2}$ inhalation. Mice were decapitated; brains were removed; and, under RNAse-free conditions, hypothalami were extracted and immediately frozen on dry ice until processing. For gene expression analysis, hypothalamic tissue was sonicated in lysis/binding buffer, and total RNA was extracted using the mirVana miRNA Isolation Kit (Life Technologies), as outlined in the manufacturer protocol. RNA concentration was measured with a NanoDrop (Thermo Scientific). cDNA was synthesized using the QuantiTect Reverse Transcription Kit (Qiagen).

\section{$R T-q P C R$}

RT-qPCR was performed using an AB 7500 Real-Time PCR System (Applied Biosystems) under the following standard amplification conditions: $2 \mathrm{~min}$ at $50^{\circ} \mathrm{C}, 10 \mathrm{~min}$ at $95^{\circ} \mathrm{C}$, and 40 cycles of $15 \mathrm{~s}$ at 95 followed by $1 \mathrm{~min}$ at $60^{\circ} \mathrm{C}$, as outlined in the manufacturer protocol. TaqMan Gene Expression Assays (Applied Biosystems) were used as PCR primers. The Gene symbol and Assay ID for the primers used were as follows: Rps16 (Mm01617542_g1); CNTF (Mm04213924_s1); Bdnf (Mm04230607_s1); Fgf10 (Mm00433275_m1); Ikbkb (Mm0122247_m1); Bcl2 (Mm00477631_m1); and Casp3 (Mm01195085_m1).

\section{Quantification of gene expression}

Quantification of gene expression was based on the comparative cycle threshold $(\Delta \mathrm{CT})$. Each target was run in either duplicate or triplicate, and the raw CT values were averaged. The housekeeping gene Rps16 was used as an endogenous control to which each target gene was normalized (Meadows and Byrnes, 2015). Rps16 was verified as a suitable housekeeping gene as the CT values did not differ between treatment groups. Next, the $\Delta \mathrm{CT}$ for each target gene was normalized against the highest expressing $\Delta \mathrm{CT}$ value in order to obtain the $\Delta \Delta \mathrm{CT}$.

\section{Statistical analysis}

A two-way ANOVA (diet and hormone) was run for each brain area separately. Where there were significant effects, a 
Table 1: Statistics

\begin{tabular}{|c|c|c|c|}
\hline & Data structure & Type of test & $p$ Values \\
\hline a & Normally distributed & ANOVA & 0.022 \\
\hline b & Normally distributed & ANOVA & 0.002 \\
\hline C & Normally distributed & ANOVA & 0.001 \\
\hline d & Normally distributed & ANOVA & 0.002 \\
\hline e & Normally distributed & ANOVA & 0.003 \\
\hline$f$ & Normally distributed & ANOVA & 0.003 \\
\hline g & Normally distributed & Tukey's HSD post hoc & 0.026 \\
\hline $\mathrm{h}$ & Normally distributed & Tukey's HSD post hoc & 0.021 \\
\hline i & Normally distributed & Tukey's HSD post hoc & 0.001 \\
\hline j & Normally distributed & ANOVA & 0.02 \\
\hline $\mathrm{k}$ & Normally distributed & ANOVA & 0.019 \\
\hline | & Normally distributed & ANOVA & 0.044 \\
\hline $\mathrm{m}$ & Normally distributed & Tukey's HSD post hoc & 0.11 \\
\hline$n$ & Normally distributed & Tukey's HSD post hoc & 0.15 \\
\hline 0 & Normally distributed & Tukey's HSD post hoc & 0.15 \\
\hline $\mathrm{p}$ & Normally distributed & Tukey's HSD post hoc & 0.11 \\
\hline q & Normally distributed & ANOVA & 0.023 \\
\hline$r$ & Normally distributed & ANOVA & 0.014 \\
\hline s & Normally distributed & ANOVA & 0.04 \\
\hline $\mathrm{t}$ & Normally distributed & Tukey's HSD post hoc & 0.152 \\
\hline $\mathrm{u}$ & Normally distributed & Tukey's HSD post hoc & 0.14 \\
\hline v & Normally distributed & Tukey's HSD post hoc & 0.145 \\
\hline w & Normally distributed & Tukey's HSD post hoc & 0.096 \\
\hline$x$ & Normally distributed & ANOVA & 0.043 \\
\hline y & Normally distributed & ANOVA & 0.054 \\
\hline z & Normally distributed & ANOVA & 0.048 \\
\hline aa & Normally distributed & ANOVA & $<0.001$ \\
\hline $\mathrm{bb}$ & Normally distributed & Tukey's HSD post hoc & 0.014 \\
\hline cc & Normally distributed & Tukey's HSD post hoc & 0.002 \\
\hline dd & Normally distributed & Tukey's HSD post hoc & $<0.001$ \\
\hline ee & Normally distributed & Tukey's HSD post hoc & 0.02 \\
\hline $\mathrm{ff}$ & Normally distributed & Tukey's HSD post hoc & $<0.001$ \\
\hline gg & Normally distributed & Student's $t$ test & 0.027 \\
\hline
\end{tabular}

Tukey's HSD post hoc test was used for comparisons between groups. For analysis of the RT-qPCR experiments, data were analyzed with $t$ tests. SPSS, version 21 (IBM) was used for all statistical analyses. Differences were considered statistically significant at $p<0.05$.

\section{Results}

\section{Weight and food intake}

As described above in the Materials and Methods section, the tissue analyzed in the present study was collected from a previous cohort of animals (Bless et al., 2014). As previously reported (Bless et al., 2014), animals treated with E2 ate less than animals treated with Veh, and HFD-Veh animals weighed $\sim 35 \%$ more than animals in all other treatment groups.

\section{The adult female hypothalamus generates new ER $\alpha$ - expressing cells}

Consistent with previous findings (Bless et al., 2014), the current study revealed an interaction between hormone and diet with an effect on the number of new cells throughout the female mouse ARC (Table 1; $p=0.022^{\mathrm{a}}$ for anterior regions, $p=0.002^{\mathrm{b}}$ for medial regions, and $p=0.001^{\mathrm{c}}$ for posterior regions) and $\mathrm{VMH}\left(p=0.002^{\mathrm{d}}\right.$ for anterior regions, $p=0.003^{\mathrm{e}}$ for medial regions, $p=$ $0.003^{f}$, and posterior regions). Mice consuming an HFD had increased cell proliferation that was attenuated by E2 in the medial ARC $\left(p=0.026^{9}\right)$, posterior ARC $(p=$ $\left.0.021^{\mathrm{h}}\right)$, and medial VMH $\left(p=0.001^{\mathrm{i}}\right)$.

Cells double labeled with $\mathrm{BrdU}$ and $\mathrm{ER} \alpha$ were found in all regions examined (Fig. 1; see Fig. $3 A, B$ ). As with cell proliferation, there was an interaction between hormone and diet in the number of new ER $\alpha$-expressing cells. The interaction was seen in the medial ARC $\left(F_{(1,27)}=6.19, p=\right.$ $\left.0.02^{j}\right)$, and in the anterior $\left(F_{(1,26)}=6.37, p=0.019^{k}\right)$ and medial $\left(F_{(1,25)}=4.54, p=0.044^{\prime}\right) \mathrm{VMH}$. Although further analysis revealed no significant differences between

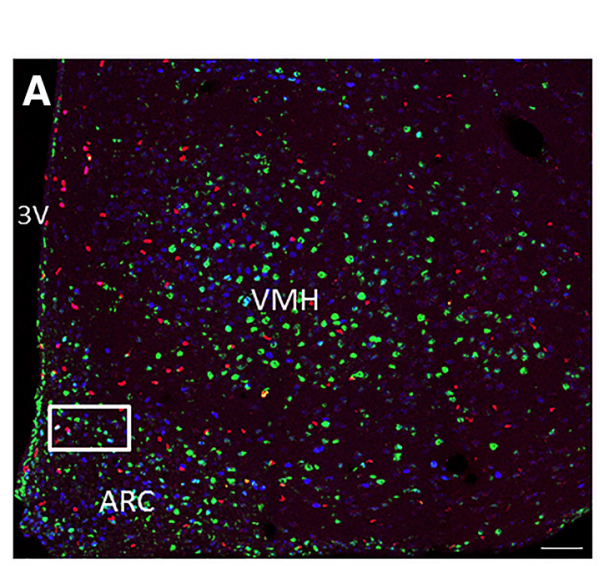

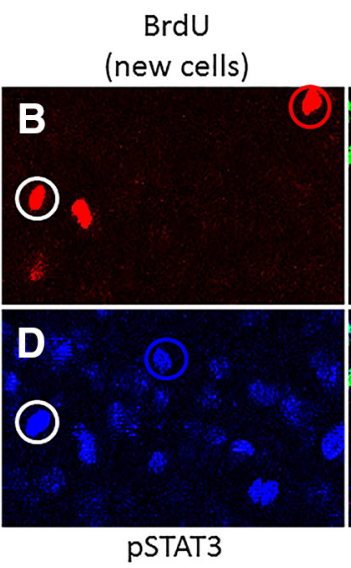

(leptin-sensitive)
$\mathrm{ER} \alpha$ (estrogen-sensitive)

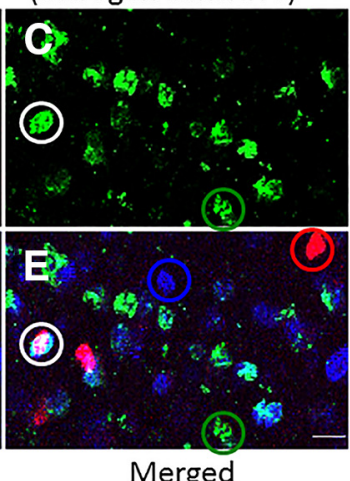

Figure 1. The adult female mouse ARC and VMH generate newborn neurons that respond to estrogens and leptin. $\boldsymbol{A}$, Photomicrograph of the medial ARC and VMH from a Veh-treated mouse fed an HFD at 400× magnification shows ER $\alpha$ (green), BrdU (red), and pSTAT3 (blue) labeling. $\boldsymbol{B}-\boldsymbol{E}$, A magnified view of the outlined area in the ARC from $\boldsymbol{A}$ shows BrdU cells (red circle; $\boldsymbol{B}$ ), ER $\alpha$ cells (green circle; $\boldsymbol{C}$ ), pSTAT3 cells (blue circle; $\boldsymbol{D}$ ), and a triple-labeled neuron (white circle; $\boldsymbol{E}$ ). 3V, Third ventricle. Scale bars: $\boldsymbol{A}, 50 \mu \mathrm{m} ; \boldsymbol{B}-\boldsymbol{E}$, $10 \mu \mathrm{m}$. 

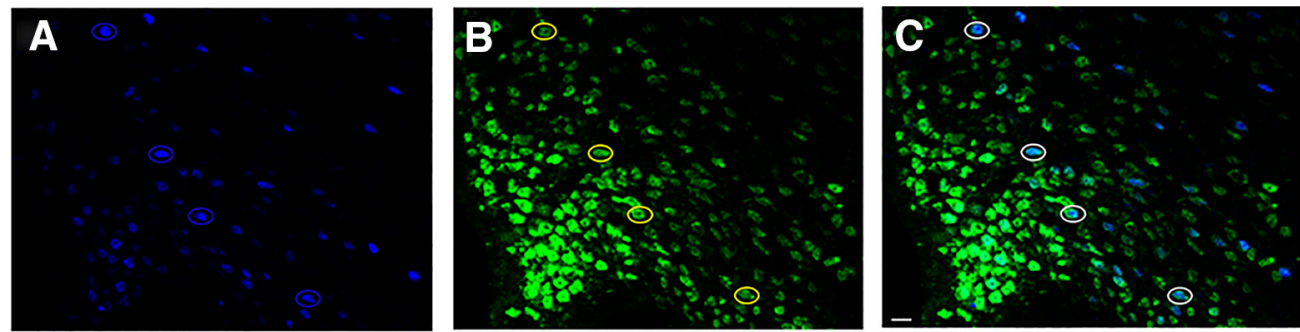

Figure 2. Virtually all pSTAT3-immunopositive cells in the medial ARC express a neuronal marker, Hu. $\boldsymbol{A}-\boldsymbol{C}$, Representative image of the medial ARC from a Veh-treated animal consuming an STND shows pSTAT3 cells (blue circle; $\boldsymbol{A}$ ), Hu cells (yellow circle; $\boldsymbol{B}$ ), and double-labeled neurons (white circle; C). Magnification, 400×. Scale bar, $10 \mu \mathrm{m}$.

groups, there was a pattern for HFD to increase the number of new ER $\alpha$-expressing cells in the medial ARC $\left(p=0.11^{\mathrm{m}}\right.$, STND-Veh vs HFD-Veh) and the medial VMH $\left(p=0.15^{n}\right.$, STND-Veh vs HFD-Veh), and for E2 to attenuate this effect $\left(p=0.15^{\circ}\right.$ for medial ARC; and $p=0.11^{p}$ for medial VMH; HFD-Veh vs HFD-E2). This pattern is consistent with the effects of HFD and E2 on cell proliferation, as described above.

\section{A subpopulation of new ER $\alpha$ neurons responds to leptin}

Images from a previous study (Bless et al., 2014) of medial $\mathrm{ARC}$ and $\mathrm{VMH}$ sections were analyzed to determine the percentage of pSTAT3-labeled cells that express the neu- ronal marker $\mathrm{Hu}$. Of the 30 randomly chosen pSTAT3immunopositive cells in the medial ARC per animal, 99.4 $\pm 0.4 \%$ also expressed $\mathrm{Hu}$, indicating that these pSTAT3 cells are neurons (Fig. 2). Similarly, in the medial VMH, $98.5 \pm 0.7 \%$ of pSTAT3 cells coexpressed the neuronal marker $\mathrm{Hu}$. These findings indicate that virtually all pSTAT3-labeled cells in the ARC and VMH of the present study are neurons.

Neurons triple labeled with $\operatorname{BrdU}, \mathrm{ER} \alpha$, and pSTAT3 were observed in every region analyzed (Figs. 1, 3C,D). There was a significant interaction between hormone and diet on the number of new neurons expressing both $\mathrm{ER} \alpha$ and pSTAT3. This effect was seen in the medial ARC $\left(F_{(1,27)}=5.88, p=0.023^{q}\right)$, and the anterior $\left(F_{(1,26)}=7.09\right.$,
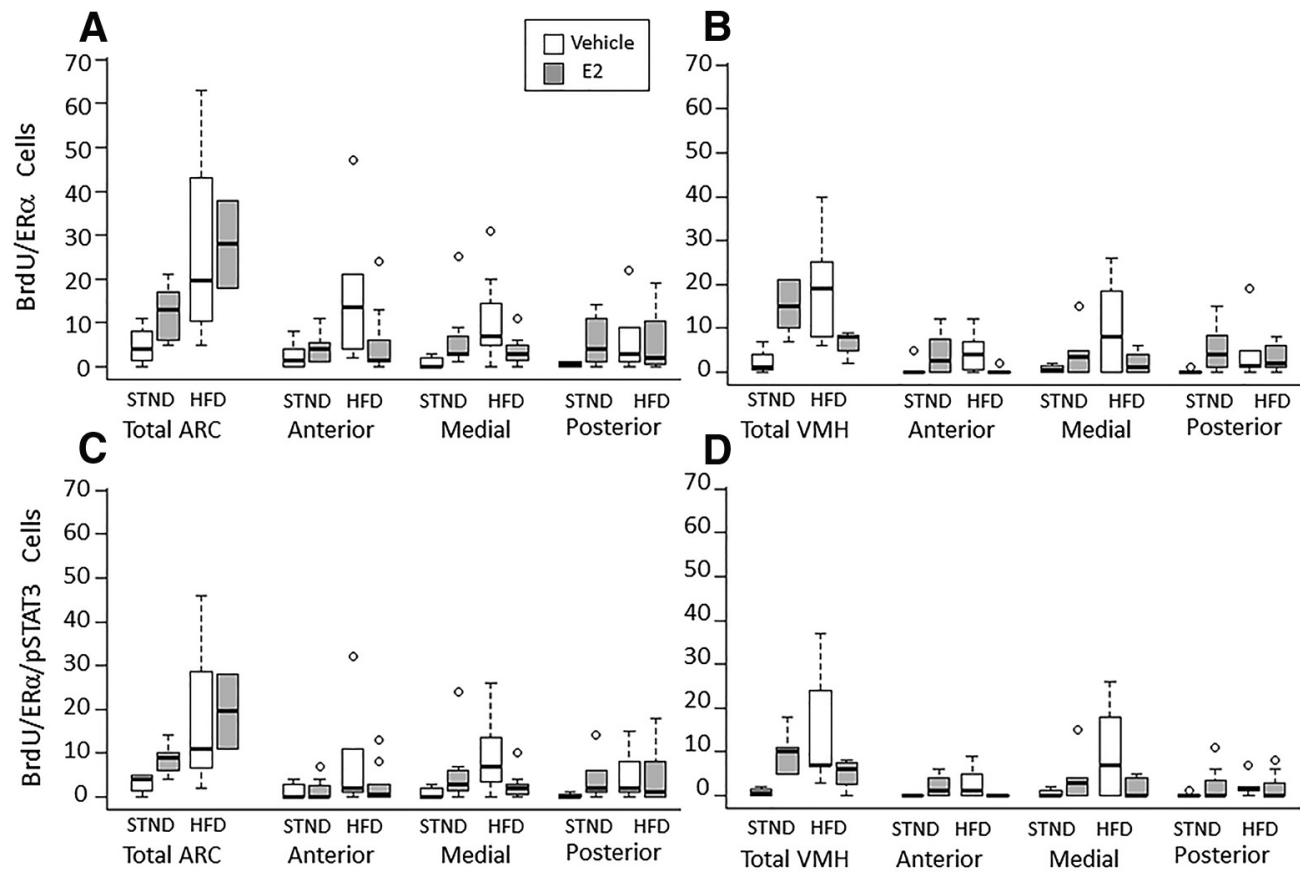

Figure 3. Estradiol and diet interact to regulate the number of newborn neurons that express ER $\alpha$ in the ARC and VMH of the adult female mouse. $\boldsymbol{A}, \boldsymbol{B}$, Double-labeled BrdU- and ER $\alpha$-expressing cells were seen through the rostral-caudal extent of the ARC $(\boldsymbol{A})$ and $\mathrm{VMH}(\boldsymbol{B})$. There was an interaction between hormone and diet with an effect on the number of newborn ER $\alpha$-expressing cells in the medial region of both areas. $\boldsymbol{C}, \boldsymbol{D}$, In the ARC $(\boldsymbol{C})$ and $\mathrm{VMH}(\boldsymbol{D})$, a subpopulation of the newborn estrogen-sensitive $(\mathrm{ER} \alpha)$ and leptin-sensitive (pSTAT3) neurons was identified. There was an interaction between hormone and diet with an effect on the number of these triple-labeled cells in the medial regions of both the ARC and VMH. Interaction between hormone and diet, $p<0.05$; post hoc analysis revealed no significant differences between groups (see text for further explanation). 

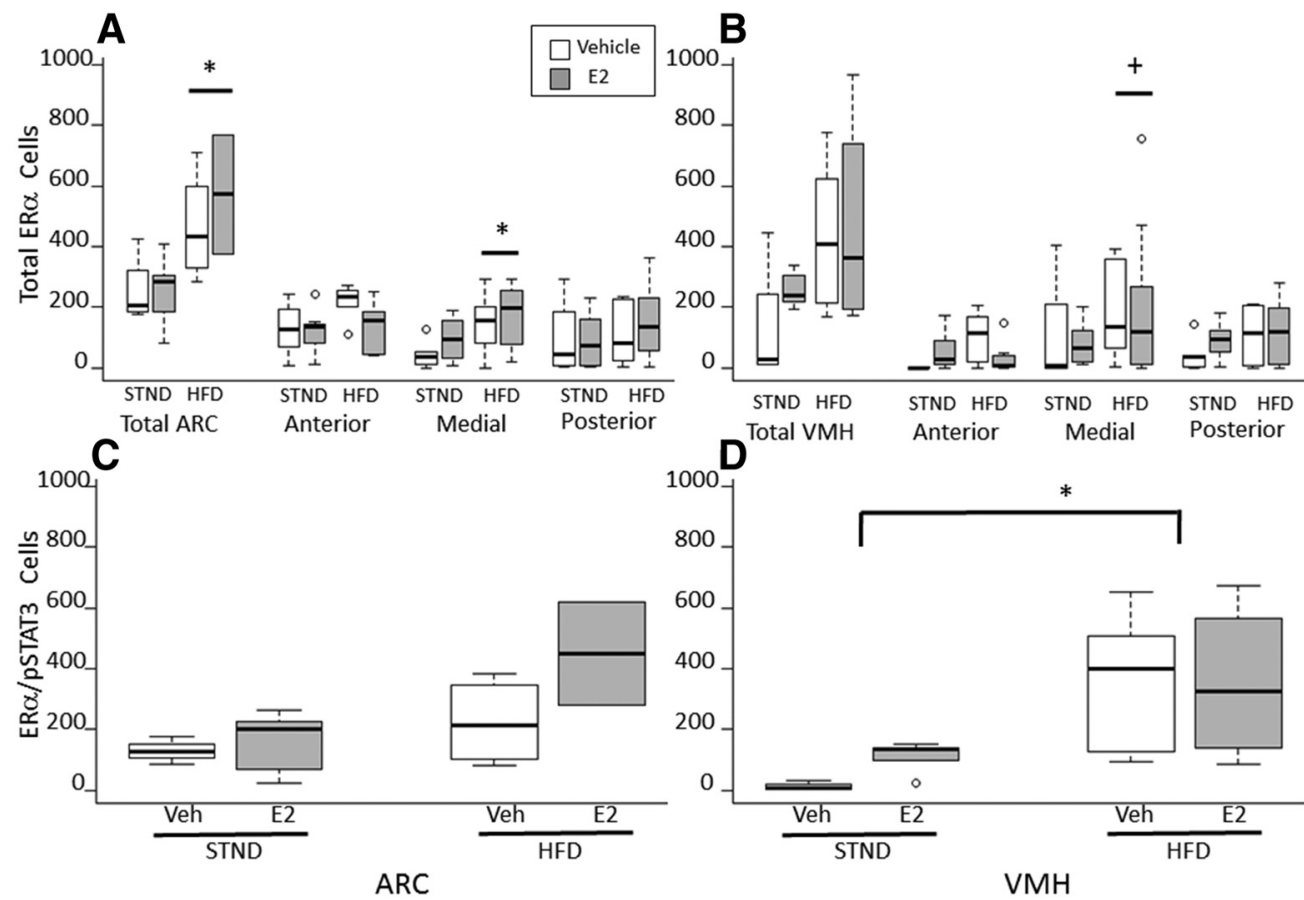

Figure 4. HFD increased the number of ER $\alpha$-expressing cells. $\boldsymbol{A}$, HFD increased the number of ER $\alpha$-expressing cells in the ARC, regardless of hormone treatment. This effect of HFD consumption was detected in the medial, but not anterior or posterior, ARC. $\boldsymbol{B}$, There was a strong trend towards an HFD-induced increase in ER $\alpha$ expression in the medial, but not anterior or posterior, VMH. $\mathbf{C}$, $\boldsymbol{D}, \mathrm{HFD}$ increased the number of leptin-sensitive ER $\alpha$ neurons in the VMH, but not in the ARC. $* p<0.05,+p=0.054, \mathrm{HFD}$ vs STND.

$\left.p=0.014^{\eta}\right)$ and medial $\left(F_{(1,25)}=4.77, p=0.04^{\mathrm{s}}\right) \mathrm{VMH}$. Although further analysis revealed no significant differences between groups, as was observed for new ER $\alpha$ cells above, there was a pattern for HFD consumption to increase the number of newborn ER $\alpha$-pSTAT3expressing cells in the medial ARC $p=0.152^{\mathrm{t}}$, STND-Veh vs HFD-Veh) and the medial VMH ( $p=0.140^{\mathrm{u}}$, STND-Veh vs HFD-Veh), and for E2 to attenuate this effect ( $p=$ $0.145^{\mathrm{v}}$ for medial ARC; and $p=0.096^{\mathrm{w}}$ for medial $\mathrm{VMH}$; HFD-Veh vs HFD-E2).

The number of ER $\alpha$-expressing cells and leptinsensitive ER $\alpha$-expressing neurons is affected by diet There was a main effect of diet on the number of ER $\alpha$-expressing cells. The number of cells that contain $\mathrm{ER} \alpha$ was greater in mice fed an HFD than those fed standard chow, regardless of hormone status (Fig. $4 A, B)$. This effect of HFD was found in the medial ARC $\left(F_{(1,27)}=4.55, p=0.043^{\times}\right)$, and a strong trend was found in the medial VMH $\left(F_{(1,25)}=4.29, p=0.054^{y}\right)$. In addition, HFD increased the number of leptin-sensitive $\mathrm{ER} \alpha\left(\mathrm{ER} \alpha^{+} / \mathrm{pSTAT}^{+}\right)$neurons in the total VMH $\left(F_{(1,17)}\right.$ $=4.697, p=0.048^{\mathrm{z}}$ ), but not in the ARC (Fig. 4C,D). There was no effect of estradiol treatment on ER $\alpha$ expression in the ARC or $\mathrm{VMH}$. These results are consistent with previous findings that long-term estradiol treatment in female mice did not alter hypothalamic ER $\alpha$ expression (Temple et al., 2001).
The density of ER $\alpha /$ pSTAT3-expressing neurons is greatest in the medial ARC

There was a main effect of ROI on the density (cells/100,000 $\mu \mathrm{m}^{2}$ ) of double-labeled ER $\alpha$ and pSTAT3 neurons across treatment groups $\left(F_{(5,154)}=5.302, p<0.001^{\text {aa. }}\right.$; Fig. 5). Post hoc analysis found that the density of double-labeled neurons was greatest in the medial ARC region compared with all other regions $\left(p=0.014^{\mathrm{bb}}\right.$ for anterior ARC, $p=0.002^{\mathrm{cc}}$ for posterior ARC, $p<0.001^{\text {dd }}$ for anterior VMH, $p=0.02^{\mathrm{ee}}$ for medial VMH, $p<0.001^{\mathrm{ff}}$ for posterior $\mathrm{VMH}$ ).

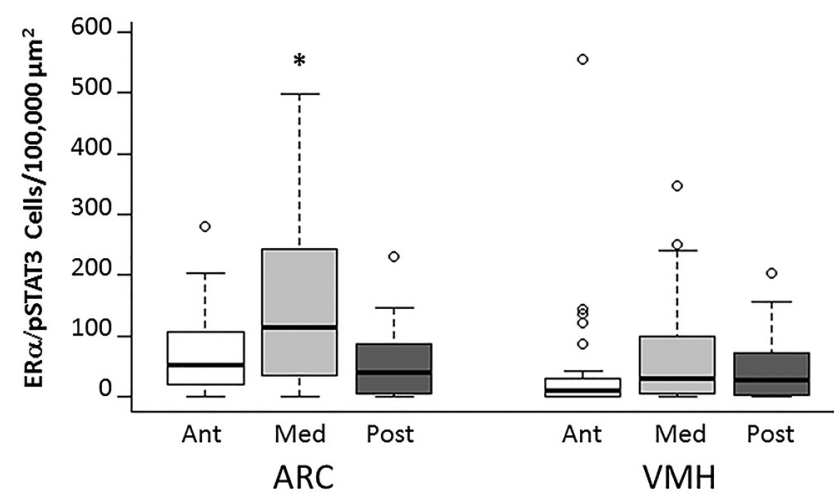

Figure 5. The medial ARC has the highest density of neurons that respond to both estrogens and leptin. The density of doublelabeled ER $\alpha$ - and pSTAT3-positive neurons was greatest in the medial ARC compared with all other brain regions. $* p<0.05$ compared with all other regions. 
Table 2: Estradiol alters hypothalamic gene expression in female mice fed a HFD

\begin{tabular}{lll}
\hline Gene of Interest & Veh-HFD & E2-HFD \\
Bcl-2 & $10.56( \pm 0.74)$ & $8.74( \pm 0.89)$ \\
BDNF & $1.23( \pm 0.13)$ & $0.77( \pm 0.24)$ \\
Caspase3 & $9.93( \pm 3.54)$ & $16.15( \pm 4.37)$ \\
CNTF & $1.80( \pm 0.54)$ & $1.04( \pm 0.44)$ \\
Fgf10 & $1.13( \pm 0.43)$ & $0.22( \pm 0.17) *$ \\
I $\kappa$ B kinase $\beta$ & $3.16( \pm 1.23)$ & $3.45( \pm 1.23)$ \\
\hline
\end{tabular}

Estradiol decreased the relative expression of Fgf10 in the hypothalamus of female mice fed a HFD.

$* p=0.027^{\mathrm{gg}} \mathrm{E} 2$ vs Veh.

\section{Fgf10 gene expression is downregulated by E2 in mice on an HFD}

RT-qPCR analysis of hypothalamic tissue from mice consuming an HFD found that estradiol treatment decreased Fgf10 gene expression compared with Veh-treated mice (Table 2; $p=0.027^{99}$ ). No differences were detected between hormone groups in $B c / 2, B D N F$, capsase3, CNTF or $I \kappa B$ gene expression. RNA integrity was verified by running all samples on a denaturing gel, resulting in a $28 \mathrm{~S} / 18 \mathrm{~S}$ ratio of $\geq 2$.

\section{Discussion}

\section{The adult female mouse brain generates new ER $\alpha$ cells}

Along with the hippocampus and olfactory bulb, it is now well accepted that the adult mammalian hypothalamus is capable of generating new neurons (Kokoeva et al., 2007). The phenotype of these newly generated hypothalamic neurons is just beginning to be elucidated in male mice (Pierce and Xu, 2010; Lee et al., 2012; McNay et al., 2012; Gouaze et al., 2013; Haan et al., 2013; Nascimento et al., 2016) and female mice (Bless et al., 2014). The current study shows that the adult female mouse brain produces new cells that express $\mathrm{ER} \alpha$, a receptor involved in reproduction (Ogawa et al., 1998; Emmen and Korach, 2003) and energy homeostasis (Heine et al., 2000; Santollo et al., 2007, 2010). Furthermore, the number of these new ER $\alpha$-expressing cells is dependent on E2 level and diet. The addition of newborn ER $\alpha$-expressing cells could function to enhance estrogen responsiveness and to provide a protective mechanism against obesity by increasing activity levels and decreasing feeding behavior (Wade, 1972; Blaustein et al., 1976; Xu et al., 2011). In addition, these newborn $\mathrm{ER} \alpha$ cells could act to modulate reproductive behavior (Musatov et al., 2006; Gao and Horvath, 2008). Studies in adult male mice have found that some new hypothalamic neurons express peptides related to energy homeostasis, such as NPY (Kokoeva et al., 2005; McNay et al., 2012; Gouaze et al., 2013) and POMC (Kokoeva et al., 2005; McNay et al., 2012; Gouaze et al., 2013). Since E2 alters the expression of both NPY and POMC (Pelletier et al., 2007; Silva et al., 2010), it will be important for future studies to investigate whether the adult female mammalian brain also generates new neurons that express these feeding-related peptides and $\mathrm{ER} \alpha$.

\section{HFD increases the number of ER $\alpha$-expressing neurons}

While there is evidence that some glial cells are leptin responsive (Kim et al., 2014a), we found that virtually all leptin-sensitive cells in the medial ARC and $\mathrm{VMH}$ also expressed the neuronal marker $\mathrm{Hu}$, indicating these hypothalamic pSTAT3 cells are neurons, and suggesting that the majority of these cells in the anterior and posterior $\mathrm{ARC}$ and $\mathrm{VMH}$ are neurons. Furthermore, many of the new hypothalamic pSTAT3 neurons identified here also express $\operatorname{ER} \alpha$, suggesting that these new neurons respond to estrogens and leptins. However, it should be noted that $\mathrm{ER} \alpha$ has been identified in glial cells (Langub and Watson, 1992; Pawlak et al., 2005), which have been implicated in energy homeostasis (Argente-Arizón et al., 2015), suggesting that $\mathrm{ER} \alpha$ can influence energy homeostasis via non-neuronal mechanisms. In addition, while it is well established that leptin induces the phosphorylation of STAT3 in the hypothalamus (Hübschle et al., 2001; Gao and Horvath, 2008), there are reports that estradiol injections can rapidly increase pSTAT3 levels in the hypothalamus within 30 min (Gao et al., 2007). Therefore, while it is possible that the slow-acting estradiol implants used in the present study induced pSTAT3, suggesting that not all hypothalamic pSTAT3-labeled cells in the present study are leptin sensitive, it is likely that the majority of the pSTAT3-labeled cells detected after leptin injection are leptin responsive. Finally, a recent study (Kim et al., 2016) suggests that the anorectic effects of estradiol may occur independently of pSTAT3 signaling pathways in the hypothalamus. It will be important for future studies to address the functional significance in energy homeostasis and reproduction of these new hypothalamic ER $\alpha$ expressing neurons that respond to leptins.

The current study found an increase in ER $\alpha$ expression in the medial aspects of both the ARC and $\mathrm{VMH}$ in mice fed an HFD compared with those fed standard chow, regardless of hormonal status. In addition, mice consuming an HFD had a higher number of leptin-sensitive $\mathrm{ER} \alpha$ expressing neurons compared with those fed standard chow. This effect was seen in the $\mathrm{VMH}$, but not in the ARC. In further support of a role for $E R \alpha$ in the $\mathrm{VMH}$ in energy homeostasis, RNAi to $\mathrm{ER} \alpha$ in this region resulted in a decreased response to E2 in weight loss and adiposity (Musatov et al., 2007). Consistent with the present findings that consuming an HFD elevates hypothalamic ER $\alpha$ levels, consuming an HFD increased ER $\alpha$ expression in the hypothalamus of prepubescent female pigs (Zhuo et al., 2014) and mouse mammary gland (Hilakivi-Clarke et al., 1998). However, long-term (16 weeks) consumption of an HFD in mice decreased hypothalamic ER $\alpha$ expression in males, but not in intact females, suggesting a sex-specific effect (Morselli et al., 2014). E2 acts through $\mathrm{ER} \alpha$ to decrease hypothalamic inflammation (Morselli et al., 2014), and decreased inflammation is correlated with weight maintenance (Yu et al., 2013). Together with the present findings, these studies suggest that HFD consumption triggers increases in hypothalamic ER $\alpha$ and downstream signaling molecules (e.g., pSTAT3) as a protective mechanism to maintain homeostasis by providing 
an increase in the components of the estrogenic-anorectic pathway.

\section{Estrogens and leptin interact in the VMH and ARC}

While coexpression of leptin receptors and ER has been localized to areas of the hypothalamus (Diano et al., 1998), the precise region of the greatest estrogenpSTAT3 sensitivity in the hypothalamus has not yet been elucidated. In the present study of the anterior, medial, and posterior $A R C$ and $\mathrm{VMH}$, the greatest density of neurons coexpressing $\mathrm{ER} \alpha$ and pSTAT3 was in the medial $A R C$, suggesting strong interaction between the estrogen and leptin signaling pathways in the medial ARC. In support, E2 microinjections directly into the ARC decrease food intake in ovariectomized rats (Santollo et al., 2011). In addition, all ARC cells containing $\mathrm{ER} \alpha$ also express leptin receptor in female rats (Diano et al., 1998).

\section{Fgf10 gene expression is associated with an increase in neurogenesis}

We tested the hypothesis that estradiol regulates hypothalamic growth factors or cytokines known to be involved in neurogenesis (Endres et al., 1998; Fink et al., 1998; Pencea et al., 2001; Kokoeva et al., 2005; Sasaki et al., 2006; Zhang et al., 2006; Yuan, 2008; Zhao et al., 2008; Choi et al., 2009; Li et al., 2012). Analysis by RTqPCR revealed that Fgf10 gene expression was greater in the hypothalamus of Veh-treated mice, indicating that estradiol treatment decreased Fgf10 gene expression. While the hypothalamic neurogenic niche has not been identified, studies have suggested that there are $\beta$-tanycytes with stem cell potential along the ventral third ventricle (Lee et al., 2012; Bolborea and Dale, 2013). Moreover, these tanycytes express Fgf10 and may be the precursors for the generation of new cells in the hypothalamus (Haan et al., 2013). Together with previous studies, the present findings suggest that endogenous estradiol downregulation of Fgf10 may play a role in cell proliferation and neurogenesis in the hypothalamus of HFD-fed animals. No changes were detected in the gene expression of other factors previously shown to have a role in cell proliferation, survival, or apoptosis (CNTF, BCl-2, caspase 3, BDNF, and IKK $\beta$; Endres et al., 1998; Pencea et al., 2001; Kokoeva et al., 2005; Sasaki et al., 2006; Li et al., 2012). Given that the whole hypothalamus was analyzed in the present study, it will be important for future experiments to use higher neuroanatomical resolution when exploring the role of these factors in neurogenesis in the ARC and VMH.

In summary, new cells were identified in the adult female hypothalamus that express ER $\alpha$. Furthermore, a subpopulation of these new $\mathrm{ER} \alpha$ cells also express pSTAT3, indicating that they are neurons. Interestingly, the birth of these new hypothalamic estrogen- and leptinresponsive neurons is influenced by diet and hormonal condition. These findings suggest a novel mechanism by which E2 can affect energy homeostasis in females.

\section{References}

Ainslie DA, Morris MJ, Wittert G, Turnbull H, Proietto J, Thorburn AW (2001) Estrogen deficiency causes central leptin insensitivity and increased hypothalamic neuropeptide $\mathrm{Y}$. Int $\mathrm{J}$ Obes Relat Metab Disord 25:1680-1688. CrossRef Medline

Argente-Arizón P, Freire-Regatillo A, Argente J, Chowen JA (2015) Role of non-neuronal cells in body weight and appetite control. Front Endocrinol (Lausanne) 6:42. CrossRef Medline

Blaustein JD, Wade GN (1976) Ovarian influences on the meal patterns of female rats. Physiol Behav 17:201-208. Medline

Blaustein JD, Gentry RT, Roy EJ, Wade GN (1976) Effects of ovariectomy and estradiol on body weight and food intake in gold thioglucose-treated mice. Physiol Behav 17:1027-1030. Medline

Bless EP, Reddy T, Acharya KD, Beltz BS, Tetel MJ (2014) Oestradiol and diet modulate energy homeostasis and hypothalamic neurogenesis in the adult female mouse. J Neuroendocrinol 26:805-816. CrossRef Medline

Bolborea M, Dale N (2013) Hypothalamic tanycytes: potential roles in the control of feeding and energy balance. Trends Neurosci 36: 91-100. CrossRef Medline

Carr MC (2003) The emergence of the metabolic syndrome with menopause. J Clin Endocrinol Metab 88:2404-2411. CrossRef Medline

Choi SH, Li Y, Parada LF, Sisodia SS (2009) Regulation of hippocampal progenitor cell survival, proliferation and dendritic development by BDNF. Mol Neurodegener 4:52. CrossRef Medline

Clegg DJ (2012) Minireview: the year in review of estrogen regulation of metabolism. Mol Endocrinol 26:1957-1960. CrossRef

Clegg DJ, Brown LM, Woods SC, Benoit SC (2006) Gonadal hormones determine sensitivity to central leptin and insulin. Diabetes 55:978-987. Medline

Diano S, Kalra SP, Sakamoto H, Horvath TL (1998) Leptin receptors in estrogen receptor-containing neurons of the female rat hypothalamus. Brain Res 812:256-259. Medline

Duarte-Guterman P, Yagi S, Chow C, Galea LA (2015) Hippocampal learning, memory, and neurogenesis: Effects of sex and estrogens across the lifespan in adults. Horm Behav 74:37-52. CrossRef Medline

Emmen JM, Korach KS (2003) Estrogen receptor knockout mice: phenotypes in the female reproductive tract. Gynecol Endocrinol 17:169-176. Medline

Endres M, Namura S, Shimizu-Sasamata M, Waeber C, Zhang L, Gómez-Isla T, Hyman BT, Moskowitz MA (1998) Attenuation of delayed neuronal death after mild focal ischemia in mice by inhibition of the caspase family. J Cereb Blood Flow Metab 18:238247. CrossRef Medline

Fink K, Zhu J, Namura S, Shimizu-Sasamata M, Endres M, Ma J, Dalkara T, Yuan J, Moskowitz MA (1998) Prolonged therapeutic window for ischemic brain damage caused by delayed caspase activation. J Cereb Blood Flow Metab 18:1071-1076. CrossRef Medline

Frank A, Brown LM, Clegg DJ (2014) The role of hypothalamic estrogen receptors in metabolic regulation. Front Neuroendocrinol 35:550-557. CrossRef Medline

Frontini A, Bertolotti P, Tonello C, Valerio A, Nisoli E, Cinti S, Giordano A (2008) Leptin-dependent STAT3 phosphorylation in postnatal mouse hypothalamus. Brain Res 1215:105-115. CrossRef

Galea LA, Spritzer MD, Barker JM, Pawluski JL (2006) Gonadal hormone modulation of hippocampal neurogenesis in the adult. Hippocampus 16:225-232. Medline

Gao Q, Horvath TL (2008) Cross-talk between estrogen and leptin signaling in the hypothalamus. Am J Physiol Endocrinol Metab 294:E817-E826. CrossRef Medline

Gao Q, Mezei G, Nie Y, Rao Y, Choi CS, Bechmann I, Leranth C, Toran-Allerand D, Priest CA, Roberts JL, Gao XB, Mobbs C, Shulman GI, Diano S, Horvath TL (2007) Anorectic estrogen mimics leptin's effect on the rewiring of melanocortin cells and Stat3 signaling in obese animals. Nat Med 13:89-94. CrossRef

Gouaze A, Brenachot X, Rigault C, Krezymon A, Rauch C, Nedelec E, Lemoine A, Gascuel J, Bauer S, Penicaud L, Benani A (2013) Cerebral cell renewal in adult mice controls the onset of obesity. PLoS One 8:e72029. Medline 
Guo SS, Zeller C, Chumlea WC, Siervogel RM (1999) Aging, body composition, and lifestyle: the Fels Longitudinal Study. Am J Clin Nutr 70:405-411. Medline

Haan N, Goodman T, Najdi-Samiei A, Stratford CM, Rice R, El Agha E, Bellusci S, Hajihosseini MK (2013) Fgf10-expressing tanycytes add new neurons to the appetite/energy-balance regulating centers of the postnatal and adult hypothalamus. J Neurosci 33:61706180. CrossRef Medline

Heine PA, Taylor JA, Iwamoto GA, Lubahn DB, Cooke PS (2000) Increased adipose tissue in male and female estrogen receptoralpha knockout mice. Proc Natl Acad Sci U S A 97:12729-12734. CrossRef

Hilakivi-Clarke L, Stoica A, Raygada M, Martin MB (1998) Consumption of a high-fat diet alters estrogen receptor content, protein kinase $\mathrm{C}$ activity, and mammary gland morphology in virgin and pregnant mice and female offspring. Cancer Res 58:654-660. Medline

Hosono T, Chen XM, Zhang YH, Kanosue K (1997) Effects of estrogen on thermoregulatory responses in freely moving female rats. Ann N Y Acad Sci 813:207-210. Medline

Hübschle T, Thom E, Watson A, Roth J, Klaus S, Meyerhof W (2001) Leptin-induced nuclear translocation of STAT3 immunoreactivity in hypothalamic nuclei involved in body weight regulation. J Neurosci 21:2413-2424. Medline

Ingberg E, Theodorsson A, Theodorsson E, Strom JO (2012) Methods for long-term $17 \beta$-estradiol administration to mice. Gen Comp Endocrinol 175:188-193. CrossRef Medline

Kim JG, Suyama S, Koch M, Jin S, Argente-Arizon P, Argente J, Liu ZW, Zimmer MR, Jeong JK, Szigeti-Buck K, Gao Y, GarciaCaceres C, Yi CX, Salmaso N, Vaccarino FM, Chowen J, Diano S, Dietrich MO, Tschop MH, Horvath TL (2014a) Leptin signaling in astrocytes regulates hypothalamic neuronal circuits and feeding. Nat Neurosci 17:908-910. Medline

Kim JS, Rizwan MZ, Clegg DJ, Anderson GM (2016) Leptin signaling is not required for anorexigenic estradiol effects in female mice. Endocrinology 157:1991-2001. CrossRef Medline

Kim YF, Sandeman DC, Benton JL, Beltz BS (2014b) Birth, survival and differentiation of neurons in an adult crustacean brain. Dev Neurobiol 74:602-615. CrossRef Medline

Kokoeva MV, Yin H, Flier JS (2005) Neurogenesis in the hypothalamus of adult mice: potential role in energy balance. Science 310:679-683. CrossRef Medline

Kokoeva MV, Yin H, Flier JS (2007) Evidence for constitutive neural cell proliferation in the adult murine hypothalamus. J Comp Neurol 505:209-220. CrossRef Medline

Kudwa AE, Harada N, Honda SI, Rissman EF (2009) Regulation of progestin receptors in medial amygdala: estradiol, phytoestrogens and sex. Physiol Behav 97:146-150. CrossRef Medline

Langub MC Jr, Watson RE Jr (1992) Estrogen receptorimmunoreactive glia, endothelia, and ependyma in guinea pig preoptic area and median eminence: electron microscopy. Endocrinology 130:364-372. CrossRef Medline

Lee DA, Bedont JL, Pak T, Wang H, Song J, Miranda-Angulo A, Takiar V, Charubhumi V, Balordi F, Takebayashi H, Aja S, Ford E, Fishell G, Blackshaw S (2012) Tanycytes of the hypothalamic median eminence form a diet-responsive neurogenic niche. Nat Neurosci 15:700-702. CrossRef Medline

Lee DA, Yoo S, Pak T, Salvatierra J, Velarde E, Aja S, Blackshaw S (2014) Dietary and sex-specific factors regulate hypothalamic neurogenesis in young adult mice. Front Neurosci 8:157. CrossRef Medline

Li J, Tang Y, Cai D (2012) IKK $\beta / \mathrm{NF}-\kappa \mathrm{B}$ disrupts adult hypothalamic neural stem cells to mediate a neurodegenerative mechanism of dietary obesity and pre-diabetes. Nat Cell Biol 14:999-1012. CrossRef Medline

Li J, Tang Y, Purkayastha S, Yan J, Cai D (2014) Control of obesity and glucose intolerance via building neural stem cells in the hypothalamus. Mol Metab 3:313-324. CrossRef Medline
McNay DE, Briançon N, Kokoeva MV, Maratos-Flier E, Flier JS (2012) Remodeling of the arcuate nucleus energy-balance circuit is inhibited in obese mice. J Clin Invest 122:142-152. CrossRef Medline

Meadows KL, Byrnes EM (2015) Sex- and age-specific differences in relaxin family peptide receptor expression within the hippocampus and amygdala in rats. Neuroscience 284:337-348. CrossRef Medline

Morselli E, Fuente-Martin E, Finan B, Kim M, Frank A, GarciaCaceres C, Navas CR, Gordillo R, Neinast M, Kalainayakan SP, Li DL, Gao Y, Yi CX, Hahner L, Palmer BF, Tschöp MH, Clegg DJ (2014) Hypothalamic PGC-1 $\alpha$ protects against high-fat diet exposure by regulating ER $\alpha$. Cell Rep 9:633-645. CrossRef Medline

Musatov S, Chen W, Pfaff DW, Kaplitt MG, Ogawa S (2006) RNAimediated silencing of estrogen receptor $\{$ alpha\} in the ventromedial nucleus of hypothalamus abolishes female sexual behaviors. Proc Natl Acad Sci U S A 103:10456-10460. CrossRef Medline

Musatov S, Chen W, Pfaff DW, Mobbs CV, Yang XJ, Clegg DJ, Kaplitt MG, Ogawa S (2007) Silencing of estrogen receptor-alpha in the ventromedial nucleus of hypothalamus leads to metabolic syndrome. Proc Natl Acad Sci U S A 104:2501-2506. CrossRef Medline

Naaz A, Zakroczymski M, Heine P, Taylor J, Saunders P, Lubahn D, Cooke PS (2002) Effect of ovariectomy on adipose tissue of mice in the absence of estrogen receptor alpha (ERalpha): a potential role for estrogen receptor beta (ERbeta). Horm Metab Res 34:758763. CrossRef Medline

Nascimento LF, Souza GF, Morari J, Barbosa GO, Solon C, Moura RF, Victorio SC, Ignacio-Souza LM, Razolli DS, Carvalho HF, Velloso LA (2016) Omega-3 fatty acids induce neurogenesis of predominantly POMC-expressing cells in the hypothalamus. Diabetes 65:673-686.

Nestor CC, Kelly MJ, Rønnekleiv OK (2014) Cross-talk between reproduction and energy homeostasis: central impact of estrogens, leptin and kisspeptin signaling. Horm Mol Biol Clin Investig 17:109-128. CrossRef

Ogawa S, Eng V, Taylor J, Lubahn DB, Korach KS, Pfaff DW (1998) Roles of estrogen receptor-alpha gene expression in reproduction-related behaviors in female mice. Endocrinology 139: 5070-5081. CrossRef Medline

Opas EE, Gentile MA, Kimmel DB, Rodan GA, Schmidt A (2006) Estrogenic control of thermoregulation in ERalphaKO and ERbetaKO mice. Maturitas 53:210-216. CrossRef Medline

Park HK, Ahima RS (2015) Physiology of leptin: energy homeostasis, neuroendocrine function and metabolism. Metabolism 64:24-34. CrossRef Medline

Pawlak J, Karolczak M, Krust A, Chambon P, Beyer C (2005) Estrogen receptor-alpha is associated with the plasma membrane of astrocytes and coupled to the MAP/Src-kinase pathway. Glia 50:270-275. CrossRef Medline

Pawluski JL, Brummelte S, Barha CK, Crozier TM, Galea LA (2009) Effects of steroid hormones on neurogenesis in the hippocampus of the adult female rodent during the estrous cycle, pregnancy, lactation and aging. Front Neuroendocrinol 30:343-357. CrossRef

Paxinos G, Franklin KBJ (2004) The mouse brain in stereotaxic coordinates, Ed 2. Amsterdam: Elsevier Academic.

Pelletier G, Li S, Luu-The V, Labrie F (2007) Oestrogenic regulation of pro-opiomelanocortin, neuropeptide $Y$ and corticotrophinreleasing hormone mRNAs in mouse hypothalamus. J Neuroendocrinol 19:426-431. CrossRef

Pencea V, Bingaman KD, Wiegand SJ, Luskin MB (2001) Infusion of brain-derived neurotrophic factor into the lateral ventricle of the adult rat leads to new neurons in the parenchyma of the striatum, septum, thalamus, and hypothalamus. J Neurosci 21:6706-6717. Medline

Pierce AA, Xu AW (2010) De novo neurogenesis in adult hypothalamus as a compensatory mechanism to regulate energy balance. $J$ Neurosci 30:723-730. CrossRef Medline

Qiu J, Bosch MA, Tobias SC, Krust A, Graham SM, Murphy SJ, Korach KS, Chambon P, Scanlan TS, Rønnekleiv OK, Kelly MJ (2006) A G-protein-coupled estrogen receptor is involved in hypo- 
thalamic control of energy homeostasis. J Neurosci 26:56495655. CrossRef

Rissman EF, Heck AL, Leonard JE, Shupnik MA, Gustafsson JA (2002) Disruption of estrogen receptor beta gene impairs spatial learning in female mice. Proc Natl Acad Sci U S A 99:3996-4001. CrossRef Medline

Rojczyk-Gołębiewska E, Pałasz A, Wiaderkiewicz R (2014) Hypothalamic subependymal niche: a novel site of the adult neurogenesis. Cell Mol Neurobiol 34:631-642. CrossRef

Rosenbaum M, Leibel RL (2014) 20 years of leptin: role of leptin in energy homeostasis in humans. J Endocrinol 223:T83-T96. CrossRef Medline

Sahu A (2003) Leptin signaling in the hypothalamus: emphasis on energy homeostasis and leptin resistance. Front Neuroendocrinol 24:225-253. Medline

Santollo J, Wiley MD, Eckel LA (2007) Acute activation of ER alpha decreases food intake, meal size, and body weight in ovariectomized rats. Am J Physiol Regul Integr Comp Physiol 293:R2194R2201. CrossRef Medline

Santollo J, Katzenellenbogen BS, Katzenellenbogen JA, Eckel LA (2010) Activation of ER $\alpha$ is necessary for estradiol's anorexigenic effect in female rats. Horm Behav 58:872-877. CrossRef Medline

Santollo J, Torregrossa AM, Eckel LA (2011) Estradiol acts in the medial preoptic area, arcuate nucleus, and dorsal raphe nucleus to reduce food intake in ovariectomized rats. Horm Behav 60:86-93. CrossRef Medline

Sasaki T, Kitagawa K, Yagita Y, Sugiura S, Omura-Matsuoka E, Tanaka S, Matsushita K, Okano H, Tsujimoto Y, Hori M (2006) $\mathrm{Bcl} 2$ enhances survival of newborn neurons in the normal and ischemic hippocampus. J Neurosci Res 84:1187-1196. CrossRef Medline

Silva LE, Castro M, Amaral FC, Antunes-Rodrigues J, Elias LL (2010) Estradiol-induced hypophagia is associated with the differential mRNA expression of hypothalamic neuropeptides. Braz J Med Biol Res 43:759-766. Medline
Temple JL, Fugger HN, Li X, Shetty SJ, Gustafsson J, Rissman EF (2001) Estrogen receptor beta regulates sexually dimorphic neural responses to estradiol. Endocrinology 142:510-513. CrossRef Medline

van Praag H, Schinder AF, Christie BR, Toni N, Palmer TD, Gage FH (2002) Functional neurogenesis in the adult hippocampus. Nature 415:1030-1034. CrossRef Medline

Varela L, Horvath TL (2012) Leptin and insulin pathways in POMC and AgRP neurons that modulate energy balance and glucose homeostasis. EMBO Rep 13:1079-1086. CrossRef Medline

Wade GN (1972) Gonadal hormones and behavioral regulation of body weight. Physiol Behav 8:523-534. Medline

Xu Y, Nedungadi TP, Zhu L, Sobhani N, Irani BG, Davis KE, Zhang X, Zou F, Gent LM, Hahner LD, Khan SA, Elias CF, Elmquist JK, Clegg DJ (2011) Distinct hypothalamic neurons mediate estrogenic effects on energy homeostasis and reproduction. Cell Metab 14:453-465. CrossRef Medline

Yu Y, Wu Y, Szabo A, Wu Z, Wang H, Li D, Huang XF (2013) Teasaponin reduces inflammation and central leptin resistance in diet-induced obese male mice. Endocrinology 154:31303140. CrossRef Medline

Yuan TF (2008) BDNF signaling during olfactory bulb neurogenesis. J Neurosci 28:5139-5140. CrossRef Medline

Zhang R, Xue YY, Lu SD, Wang Y, Zhang LM, Huang YL, Signore AP, Chen J, Sun FY (2006) Bcl-2 enhances neurogenesis and inhibits apoptosis of newborn neurons in adult rat brain following a transient middle cerebral artery occlusion. Neurobiol Dis 24:345-356. CrossRef Medline

Zhao C, Deng W, Gage FH (2008) Mechanisms and functional implications of adult neurogenesis. Cell 132:645-660. CrossRef Medline

Zhuo Y, Zhou D, Che L, Fang Z, Lin Y, Wu D (2014) Feeding prepubescent gilts a high-fat diet induces molecular changes in the hypothalamus-pituitary-gonadal axis and predicts early timing of puberty. Nutrition 30:890-896. CrossRef Medline 